\title{
Explosive Fissure Eruption of a Large Kimberlite Pipe: Venetia K01 Kimberlite Pipe, Limpopo, RSA
}

\author{
M.A. Tait ${ }^{1}$ and R.J. Brown ${ }^{2}$ \\ ${ }^{1}$ De Beers Group Services, Mineral Resource Management, Johannesburg, South Africa \\ (Mark.Tait@debeersgroup.com). ${ }^{2}$ Dept. of Earth Sciences, University of Bristol, UK.
}

\section{Introduction}

The Venetia K01 kimberlite pipe is the largest within South Africa's Cambrian Venetia Kimberlite Cluster. An array of lithofacies has been identified that give insight into the depositional processes that operated during pipe in-fill. A complex, multi-phase volcanic eruption, perhaps analogous to modern, structurallycontrolled, fissure-type eruptions is described.
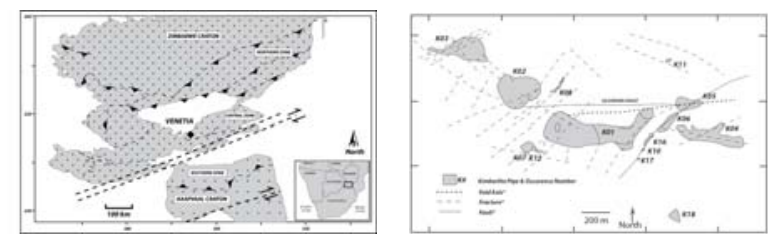

Figure 1: Regional geology of the Limpopo Mobile Belt (After Barton et al., 2003). Figure 2: The Venetia Kimberlite Cluster, highlighting the strong structural control over pipe emplacement. (After Kurszlaukis \& Barnett, 2003).

\section{Geological Setting}

The $519 \pm 6$ Ma Venetia Kimberlite Cluster is situated within the Neo-Archaean to Proterozoic central zone of the Limpopo Mobile Belt that is described as an ancient suture zone between the Archaean Zimbabwe and Kaapvaal cratons (Figure 1). The local geology comprises a complex package of meta-sedimentary and upper amphibolite to granulite facies gneissic rocks, with a number of cross cutting $\sim 2.0 \mathrm{Ga}$ dolerite sills identified (Barton et al., 2003). The volcanic field comprises 15 known kimberlite occurrences, of which the $\sim 12.7$ ha K01 pipe is the largest and most economically significant.

A complex pre-existing regional structure was instrumental in controlling volcanism, with many occurrences defined by extremely irregular 3-D geometries (Kurszlaukis \& Barnett, 2003; Figure 2). $\mathrm{K} 01$ is characterised by a clear elongation along its E$\mathrm{W}$ axis and an irregular NNE-SSW extension on its eastern margin, parallel to the major Lezel-Tina shear zone (Figure2, 3).

\section{Methodology}

From 2005-2007, detailed geological mapping at 1:500 scale of $\sim 6.2 \mathrm{~km}$ of bench exposure has been coupled with analysis of $\sim 11.7 \mathrm{~km}$ of drill core to provide 3dimensional control on the internal architecture of the K01 pipe. This has been supplemented by review of $\sim 250$ thin sections and geochemical analysis. A 3D digital model of the geology of K01 has been created JEMCOM 6.1.2

\section{Geology of the K01 Pipe \\ Key Lithofacies}

At the current mining level ( $200 \mathrm{~m}$ below surface), the most important lithofacies is described as massive volcaniclastic kimberlite (MVK, Figure 4A). This is a matrix-supported, crudely homogeneous lithofacies that exhibits local compositional and textural variations. The unit is dominated by serpentinised olivine crystals (30-50 vol. \%), many of which are characterised by a thin altered rim. A variety of partially altered basement and surface derived crustal lithics (5-30 vol.\%) is present, along with various mantle xenoliths ( $<5$ vol. \%) that are all set within a green to grey serpentine-rich matrix, with variable amounts of clay, phlogopite, microlitic clinopyroxene and carbonate identified. Minor amounts of opaque oxides are observed. A subtle and gradational change is observed in the texture of this lithofacies from east to west (Skinner \& Marsh, 2004) and a distinct subvertical fabric is common, defined by the alignment of platy olivine crystals and lithic fragments (Walters et al., 2006; Gernon, 2007). Lensoidal lithic concentration zones are localised internally.

A brown to red, matrix-rich kimberlite, typified by plastically-deformed clasts of tuffaceous mudstone outcrops along the western pipe margins (RedVK, Figure 4B). The unit is characterised by a significantly lower abundance of olivine crystals ( $<20$ vol. \%) and rare juvenile pyroclasts. Lithic content is higher than MVK (15-50\%) and is dominated by abundant oxidised vesicular basalt and sandstone clasts from the $\sim 1.8 \mathrm{Ga}$ Waterberg Formation (WFm). As there is no WFm, observed in the present-day local geology, the source for these clasts has been eroded since volcanism. Quartz, feldspar and other xenocrystic phases are also common in the matrix of this internally variable, clayrich rock and locally, a crude internal fabric dipping into the pipe at $35-45^{\circ}$ is mapped. Soft-sediment deformational structures are observed (Figure 4B).

A coarse-grained, clast-supported lithofacies occurs in the centre of the pipe and is comprised of abundant sub-spherical lapilli to bomb-sized fragments, each comprising a xenolithic or xenocrystic (serpentinised olivine) core surrounded by a shell of coherent porphyritic kimberlite (PKL).

Around the pipe margins, 4 distinct bodies of coherent kimberlite (CK, Figure 4E) are recognised, each with its own internal textural variations (Skinner \& Marsh, 2004; Medlin \& Tait, this volume).

Crudely layered breccias are mapped at many of the pipe contacts (CRB, VKBr; Figure 4C). These 
comprise (30-90 vol. \%) lithic lapilli, blocks and boulders supported in a fine- to coarse-grained, ashsized matrix.

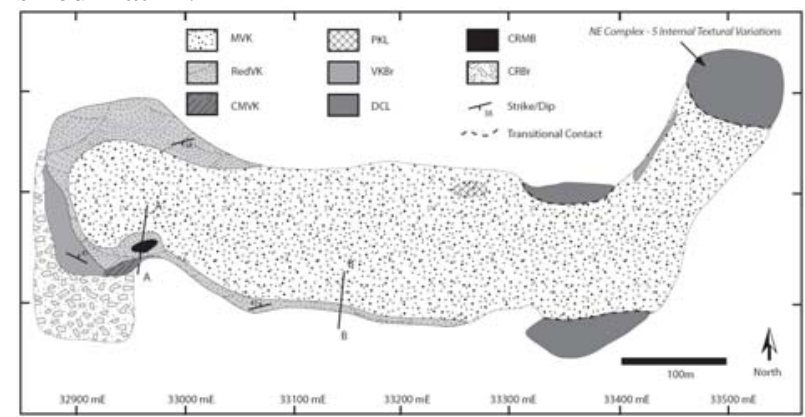

Figure 3: Simplified map of the surface geology of the K01 pipe (mapped from 168-228 m below surface)

\section{The Question of Geological Continuity}

Deep drilling has shown the internal pipe geology at depth to be different to that exposed at surface (Figure 5,6 ). At depths beneath $\sim 450 \mathrm{~m}$, there is no evidence for the mudstone-rich RedVK lithofacies and the most important lithofacies is a dark grey to black, olivinerich rock, described as dark volcaniclastic kimberlite (DVK; Figure 4F). Altered olivine macrocrysts dominate ( $<22 \mathrm{~mm}, 40-50$ vol. \%), with a variably abundant, moderately to intensely altered, angular to sub-rounded lithic content (7-30 vol. \%). The rock has a generally coherent texture, with localised clastic domains recognised, particularly across the MVKDVK boundary (Figure 5). Pools of clear serpentine and carbonate are common in the phlogopite and cpxrich matrix, accentuating the localised clastic appearance of the rock. Juvenile pyroclasts are observed (rare) and a notable increase in the modal abundance of opaque oxides distinguishes this rock. This unit is (broadly) texturally consistent across the breadth of the pipe and is present to depths $<1000 \mathrm{~m}$ below surface. Local variations in texture, grainsize, and in lithic and crystal content are apparent, but not modelled due to a lack of 3-D spatial control.

\section{Pipe Architecture}

At surface, contacts between the marginal RedVK and $\mathrm{VKBr}$ and MVK are sharp and dip steeply towards the centre of the pipe. Sharp contacts also define the boundary of the PKL lithofacies, which is modelled as a conical body that pinches out at $\sim 400 \mathrm{~m}$ depth. Contacts between the $4 \mathrm{CK}$ domains and the adjacent clastic facies are described as predominantly gradational, suggesting a close genetic relationship between the clastic pipe-filling and coherent lithofacies. The contact between DVK and MVK is described as a rapid transition, occurring over $\sim 2-5 \mathrm{~m}$ (Fig 6).

Figure 4 (opposite): 4A: MVK. 4B: RedVK. Note the plastically deformed mudstone clast $4 \mathrm{C}$ : $\mathrm{VKBr}$. Observe the clear alignment of lithic blocks. 4D: PKL. Each lapillus is defined by a porphyritic coherent kimberlite coating 4E: CKNE. 4F: DVK. The dark grey matrix and altered lithic clasts typify this unit. Note the presence of two kimberlitic dykes.

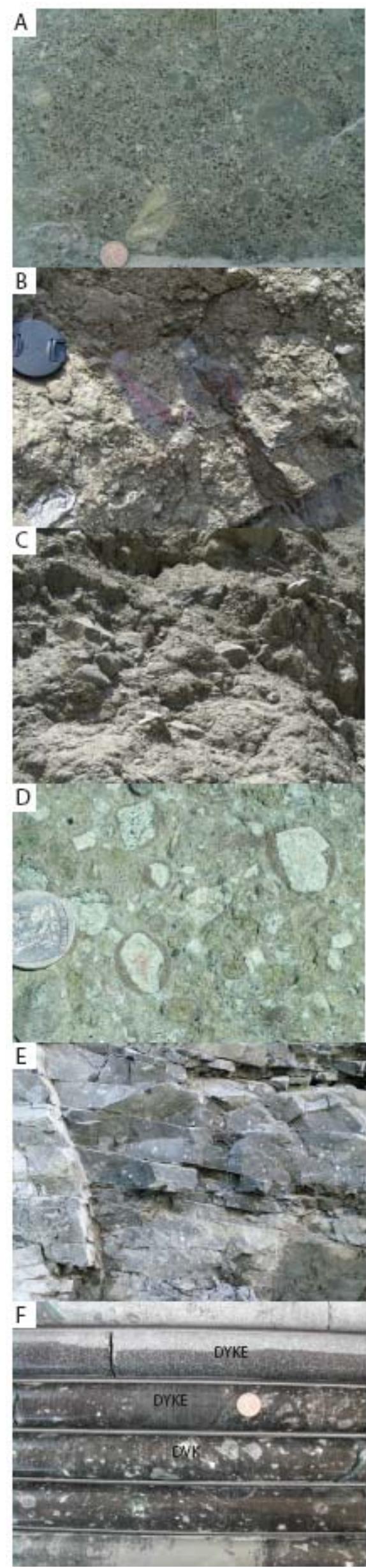




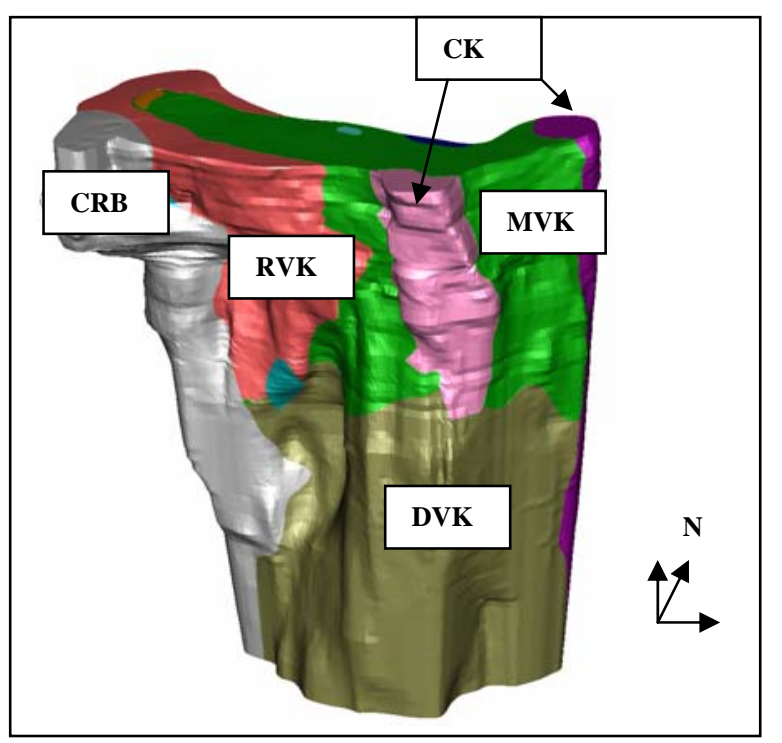

Figure 5: 3-D Geological Model of the K01 Pipe. The model has a vertical extent of $\sim 1050 \mathrm{~m}$.

\section{Discussion and Interpretation}

The MVK is interpreted as a modified pyroclastic rock. The vertical fabric is consistent with fluidisation and mixing of the deposit, which is also consistent with the apparent fines-depletion of the rock. The internal structure and textural variations seen can be attributed to internal variations within the fluidised bed and, more importantly, to the systematic and step-wise closing down of the fluidised system (Gernon, 2007). We believe that the rock matrix is the result of hydrothermal crystallisation within a coarsely packed, porous deposit (Stripp et al., 2006). The marginal RedVK lithofacies was largely derived from the mixing and transport of material predominantly located at surface. Subsidence of this material along the pipe margins may have been synchronous with fluidisation and similar structures have been observed in experimental studies (Gernon, 2007). The marginal CK units are interpreted as largely pyroclastic deposits, based on gradational contacts and internal textures (Medlin \& Tait, this volume). These may represent conduits feeding the upper parts of the volcano. The change from MVK to DVK represents a change in eruption dynamics and (post-) depositional process. The transitional nature of the contact and the locally clastic nature of the DVK indicate that pyroclastic processes were also important in the lower parts of the pipe. The textural change may be the result of pyroclast agglutination or sintering (e.g. Guest \& Rogers, 1967). We propose that $\mathrm{K} 01$ is the result of a complex, structurally-controlled volcanic eruption, involving multiple phases of pipe excavation and in-fill (Sparks et al., 2006). Predominantly pyroclastic processes controlled pipe infill. The distinctive shape of the pipe and the internal arrangement of lithofacies appear consistent with a sequence of fissure-controlled explosive events. Syn- and post-depositional modifying factors, including clast sintering and hydrothermal alteration are largely responsible for the textures nhcorved.

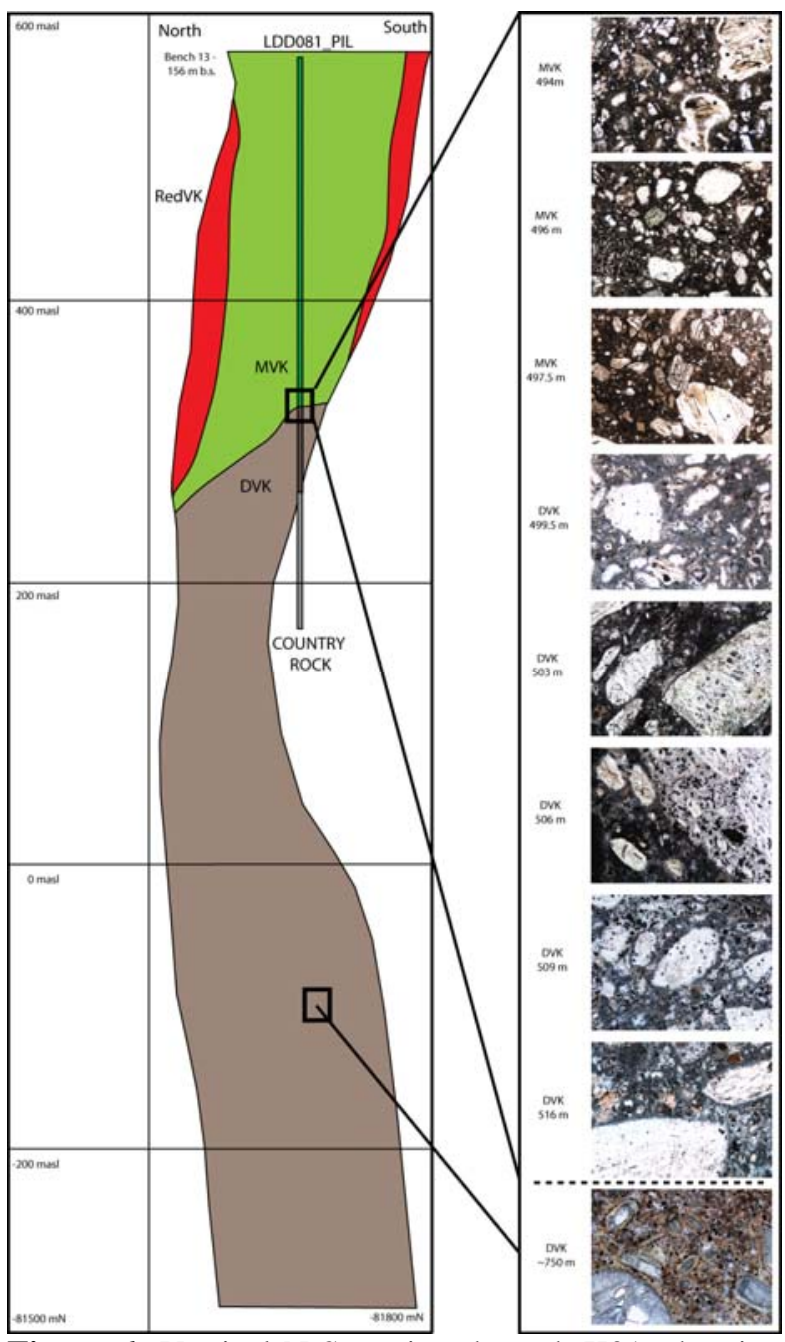

Figure 6: Vertical N-S section through K01, showing the textural change observed across the MVK-DVK boundary. Depths are relative to present surface.

\section{References}

Barton, J.M., Barnett, W.P., Barton, E.S., Barnett, M., Doorgapershad, A., Twiggs, C., Klemd, R., Martin, J., Mellonig, L. and Zenglein R. (2003). The geology of the area surrounding the Venetia kimberlite pipes, Limpopo Belt, South Africa. S. Afr. J. Geol., 106: 109-128.

Gernon, T., (2007). Fluidization and emplacement processes in kimberlite eruptions. Unpub PhD thesis, University of Bristol, pp. 299

Guest, J.E., Rogers, P.S. (1967). The sintering of glass and its relationship to welding in ignimbrites. Proc. Geol. Soc. London 1641:174-177.

Medlin, C.C., Tait, M.A. (this volume) Complexity within the Venetia K01 NE Coherent Kimberlite Facies Association.

Kurszlaukis, S., Barnett W., (2003). Volcanological and structural aspects of the Venetia Kimberlite Cluster. S. Afr. J. Geol., 106:165-192

Skinner, E.M.W., Marsh, J.S., 2004. Distinct kimberlite classes with contrasting eruption processes. Lithos, 76:183-200

Sparks, R.S.J., Baker, L., Brown, R.J., Field, M., Schumacher, J., Stripp, G. Walters, A., (2006). Dynamical constraints on kimberlite volcanism. J. Volc. Geotherm. Res, 155:18-48

Stripp, G.R., Field, M., Schumacher, J.C., Sparks, R.S.J., (2006). Post-emplacement serpentinization and related hydrothermal metamorphism in a kimberlite from Venetia, South Africa. J. Met. Geol., 24:515-534

Walters, A., Phillips, J., Brown, R.J., Field, M., Gernon, T., Stripp, G., Sparks, R.S.J., (2006). The role of fluidisation processes in the formation of volcaniclastic kimberlite. J. Volc. Geotherm. Res., 155:119-137 